\title{
Introducing Schmalenbach Journal of Business Research
}

\author{
Thomas Gehrig • Alfred Wagenhofer
}

Accepted: 29 March 2021

(C) The Author(s) 2021

\section{Mission}

We proudly present the first issue of Schmalenbach Journal of Business Research (SBUR). SBUR is an international English-language journal that publishes original high-quality research that is of wide interest to business research and practice.

SBUR contains original research from the full spectrum of business research, including accounting, finance, marketing, strategic management, organization, human resource management, production and logistics management, taxation, digital business, and entrepreneurship. SBUR provides a forum for excellent articles in such areas that are also of interest to readers from other areas. Due to this thematic inclusiveness, SBUR is also open for cross-disciplinary and multi-disciplinary research. From time to time, SBUR also plans special issues on current and highly topical themes.

Articles apply rigorous research methodologies that fit the research questions to establish their scientific findings, such as analytical modeling, archival empirical and experimental research, field and case studies. We are also considering state-ofthe-art review articles and conceptual papers on topical themes.

\section{History and Ownership}

Schmalenbach Journal of Business Research (SBUR) is the joint official journal of the Schmalenbach-Gesellschaft für Betriebswirtschaft e.V. (SG) and the Verband

T. Gehrig $(\bowtie)$

University of Vienna, Vienna, Austria

E-Mail: thomas.gehrig@univie.ac.at

A. Wagenhofer

University of Graz, Graz, Austria 
der Hochschullehrer für Betriebswirtschaft e. V. (VHB). The predecessor of the SG was founded in 1932, and the main purpose of the SG has been to promote and support science and research in business administration, and to facilitate the dialogue between research and practice. The VHB was founded in 1921 and its purpose is to promote science and research in business administration.

Both associations have been issuing their own, established journals in business research. In 2020, they decided to merge them to form SBUR. SG and VHB are committed to growing SBUR to a joint flagship journal in business research with global reach and high visibility.

SBUR builds on the Schmalenbachs Zeitschrift für betriebswirtschaftliche Forschung (ZfbF), which was founded in 1906 and is the oldest German-language academic journal in business in German-speaking countries. With the current Volume 73, SBUR replaces the previous German-language ZfbF and joins efforts with the two other former official association journals:

- Business Research (BuR), which was founded in 2008 as a pioneering Gold Open Access journal by the VHB-https://link.springer.com/journal/40685; and

- Schmalenbach Business Review (SBR), which was founded by the SG as an English-language research-oriented spin-off from the ZfbF in 2000-https://link. springer.com/journal/41464.

- Previous volumes of Schmalenbachs Zeitschrift für betriebswirtschaftliche Forschung are available at the SBUR website-https://www.springer.com/journal/ 41471.

\section{Gold Open Access}

In line with the growing global movement towards an Open Science philosophy in scientific research, and leveraging on the pioneering work of BuR, SBUR operates under Gold Open Access, which means that all published articles are freely and permanently available and accessible at the SBUR website. This way Gold Open Access maximizes visibility and impact of research globally.

This process of open access publishing has been strongly supported by research organizations such as the German DFG and has now entered a new phase: within Germany the HRK has successfully negotiated the project DEAL with Springer and Wiley-agreements with further publishers are pending-that initiates a clear transformatory process towards an open access publishing world. Similar processes are under way in other countries.

To cover the costs of the journal, the publisher Springer raises Article Processing Charges (APCs) for manuscripts that are accepted for publication in SBUR. SBUR requires no submission charges.

There are several options for authors to have the APCs covered or sponsored by research consortia or national research funding institutions. These also include agreements between national consortia or consortia of research institutions and Springer Nature (like the project DEAL in Germany). The SBUR website provides more information on eligible institutions during the submission process. 
The Schmalenbach-Gesellschaft für Betriebswirtschaft e. V. and the Verband der Hochschullehrer für Betriebswirtschaft e. V. are committed to support research in business administration and they passionately endorse the open access and Open Science transformation. For this reason, they established a funding opportunity for authors, who have no other options for reimbursement of the APCs. Authors can apply during the submission process for such funding. For further information on this funding option, authors can inquire via email to editors@sbur.info.

\section{Editorial Process}

To ensure high-quality scientific standards, articles submitted to SBUR are subject to a rigorous double-blind peer review, that is, authors are not revealed to reviewers and, conversely, reviewers do not see the names or affiliations of the authors.

With a combination of associate editors from the former three journals and new appointments, expertise is widened while continuity in the editorial processes is assured. The Associate Editors are as follows.

- Tilo Böhmann, University of Hamburg, Germany

- Marina Fiedler, University of Passau, Germany

- Karen Gedenk, University of Hamburg, Germany

- Martin Klarmann, Karlsruhe Institute of Technology, Germany

- Tobias Kretschmer, University of Munich, Germany

- Jan Landwehr, Goethe University Frankfurt, Germany

- Rainer Niemann, University of Graz, Austria

- Jana Oehmichen, University of Groningen, The Netherlands

- Jörg Rocholl, European School of Management and Technology, Berlin, Germany

- Elke Schüßler, Johannes Kepler University Linz, Austria

- Thorsten Sellhorn, University of Munich, Germany

- Martin Spann, University of Munich, Germany

- Thomas Spengler, TU Braunschweig, Germany

- Uriel Stettner, Tel Aviv University, Israel

- Hervé Stolowy, HEC Paris, Jouy-en-Josas, France

- Marliese Uhrig-Homburg, Karlsruhe Institute of Technology, Germany

- Guido Voigt, Universität Hamburg, Germany

- Michael Weber, University of Chicago, USA

A description of their respective expertise can be found at the SBUR website at https://www.springer.com/journal/41471/updates/18801266. Authors are welcome to make suggestions for associate editors to handle their submission.

SBUR is also proud to have an international Editorial Board of experts in the different areas of business research. Visit https://www.springer.com/journal/41471/ editors. Editorial board members advise the editors and are also involved in reviewing submissions.

We encourage all researchers to submit your best work to SBUR under https:// www.editorialmanager.com/sbur/. 


\section{This Issue}

SBUR plans to publish four issues every year. Since all articles are published open access, accepted articles will be available, as soon as they went through the standard production process, as online-first until they are assigned to an issue.

This first issue contains articles that were previously submitted to BuR and were subject to the review processes at BuR but could not be included in the issues by the end of 2020. They are now included in SBUR. The automatically set submission date at the beginning of these articles therefore shows only the date of the last resubmission, which is formally the first submission to SBUR. We wish to emphasize that the review process has been as rigorous as usual and as applied on all submissions to SBUR.

We would be delighted if the articles in this issue will generate your attention and interest. And we invite you to join us on our common mission.

Open Access This article is licensed under a Creative Commons Attribution 4.0 International License, which permits use, sharing, adaptation, distribution and reproduction in any medium or format, as long as you give appropriate credit to the original author(s) and the source, provide a link to the Creative Commons licence, and indicate if changes were made. The images or other third party material in this article are included in the article's Creative Commons licence, unless indicated otherwise in a credit line to the material. If material is not included in the article's Creative Commons licence and your intended use is not permitted by statutory regulation or exceeds the permitted use, you will need to obtain permission directly from the copyright holder. To view a copy of this licence, visit http://creativecommons.org/licenses/by/4. $0 /$. 